\title{
The Correlation Between Student's Reading Habit in English and Students' Reading Comprehension Ability
}

\author{
Merry Andriyani ${ }^{1)}$, Ariyanti ${ }^{2)}$, Arbain ${ }^{3)}$ \\ ${ }^{1)}$ Program Studi Pendidikan Bahasa Inggris, Fakultas Keguruan dan Ilmu Pendidikan, Universitas Widya Gama \\ Mahakam Samarinda, Indonesia \\ Jl. KH. Wahid Hasyim No. 28 RT.007 Kota Samarinda, Provinsi Kalimantan Timur \\ ${ }^{2)}$ Program Studi Pendidikan Guru Sekolah Dasar, Fakultas Keguruan dan Ilmu Pendidikan, Universitas Widya Gama \\ Mahakam Samarinda, Indonesia \\ Jl. KH. Wahid Hasyim No. 28 RT.007 Kota Samarinda, Provinsi Kalimantan Timur \\ ${ }^{3)}$ Program Studi Pendidikan Guru Sekolah Dasar, Fakultas Keguruan dan Ilmu Pendidikan, Universitas Widya Gama \\ Mahakam Samarinda, Indonesia \\ Jl. KH. Wahid Hasyim No. 28 RT.007 Kota Samarinda, Provinsi Kalimantan Timur \\ *Email Penulis Korespondensi: merryandriani0000@gmail.com, ariyanti.muflihin@gmail.com, baintigers@gmail.com,
}

\begin{abstract}
Reading comprehension can be influenced by reading habit. This research is intended to identify the students' ability in reading English. The main objective of this research is to recognize whether there is significant correlation between student's reading habit in English and students' reading comprehension ability identified through the use of students' habit questionnaire and reading test with the text was took from passage in TOEFL test. These subjects who are involved at this research are second semester of English Department in Widya Gama Mahakam Samarinda University. This research used quantitative research method. The research design of this study is correlational study. Reading test and questionnaire were used as the instruments; it was used to find out students reading comprehension (variable $\mathrm{Y}$ ) and students reading habit (variable $\mathrm{X}$ ) in order to get the data. Moreover, this research used simple random sampling technique. Population of this research was the second semester of English Department in Widya Gama Mahakam Samarinda. The researcher took 38 students as the sample. In this study the researcher computed the normality test to measure the data have a normal distribution and linearity test to measure the data is linear. The data was analyzed using product moment correlation coefficient by SPSS version 22 . The result of this research is 0.657 . From the result of this research is 0.657 was higher than the significant degree 0.05 at Sig. (2-tailed). It can be concluded the Null hypothesis (Ho) is rejected and the Alternative hypothesis (Ha) is accepted.
\end{abstract}

Keywords: Reading Habit, Reading Comprehension, Correlation 


\section{INTRODUCTION}

Reading is an active process which consists of acknowledgement and comprehension skill (Patel and Jain, 2008). Reading comprehension skill is one of keys that are associated with students' achievement. Thus, reading habit considered as one of the factors relating the success of reading comprehension. Therefore, to increase reading comprehension, it is needed to improve reading habits of the students. The benefits of readings habit are enormous, gaining reading habit will enable the students open a new world and broaden their perspective (Patel and Jain, 2008). Thus, reading habit in learning process might determine the student reading comprehension because students could get the meaning of the text more effectively. Reading comprehension can be influenced by reading habit. Practicing reading as a habit will give advantages the students to become more informed and educated.

In fact, many students in reality still have the problem in comprehending the text they read. Some reasons why more students have become poor in reading comprehension. They read less English text materials relatively little and it is the reason why they failed in English comprehension test. According to Guthrie (2008) state that reading comprehension is stuck when students lose pretension and separate from reading many students begin to surrender with reading because they effort to get understanding from the text when they read. Second, the students view reading as boring activities. Moreover, Mahfoodh (2016) said the students had also some difficulties that are related to English, which is not their first language. Beside that inadequate educational background is also one of the difficulties that affected students' reading comprehension. In addition, Ernawati (2016) also mentioned it is a fact that there is a lack of interest of reading in Indonesian culture. Some of the causes of the lack of reading habit are culture and the presence of technology such as internet, television, video game, and so forth.

As habitual activity, reading activity takes an important role to build students' character. Because reading be able to support their habit to build their character. For example, if the student good in reading habit, they become a good reader, but if the students have bad reading habit, they become a poor reader. However, reading is an important habit that every student should have. 
On the other hand, in university, level reading ability becomes even more important because students are more active in gain written information that makes reading comprehension is an asset to be success in university. Reading for comprehension is necessary to build interesting in reading. Most students need to pay attention while reading in order to get the meaning of the text. According to Hamra \& Syatriana (2012) noted that the process of getting meaning may be different among readers because of the previous knowledge and the purpose of reading the texts. Process of reading involving prediction, interpretation, observation, and evaluation happens rapidly in the readers' mind to catch meaning. In addition, Hansen (2016) states that knowledge about different genres facilitates reading various types of texts. Hence, reading texts in a range of genres is important. For students in university, the ability to read is very important. It is easier to looking for reference if they have a good ability in reading or when they do their assignments. Based on the research background above, the reason why the researcher decides the title because the researcher considered that reading habit in English is the one of influence factor for student' who have reading comprehension problem. Many students just read the text without know the meaning of the text. It is because they weak in reading habit. And the researcher decides students of English Department in Widya Gama Mahakam Samarinda because not only students' in the school have the problem of reading habit and reading comprehension but students in university have the same problem.

\section{Research Question}

1. How was the students' reading habit in English at Second Semester of English Department?

2. How was the students' reading comprehension at Second Semester of English Department?

3. Was there any correlation between students' reading habit in English and students' reading comprehension ability at Second Semester of English Department?

\section{METHODOLOGY}

Gay (2012) research is the formal, systematic application of the scientific method to the study of problem. In other word, research designs are types of inquiry within qualitative, quantitative, and mixed methods approaches that provide specific direction for procedures in a research design (Creswell, 2014). This research used correlation research to gain the data. Meanwhile, Gay (2012) defined correlational research involves collecting data to determine whether, and to what degree, a relation exists between two or more quantifiable variables.

Gay (2012) states that population is the group to which a research would like the results of a study to be generalize. Meanwhile, sample is a subgroup of the population. The group represented the characteristic of the population. The small group that is observed is called a sample and the larger group about which generalization made is called a population. In this research, the researcher took two classes at second semester of English Department. Thus, the researcher collected data from 38 students.

The instruments of this research were questionnaire and reading test. The questionnaire is about students' reading habit in English. Then, the reading test focused on examining students' reading comprehension ability. Siniscalco et al (2005) defined that the questionnaire is simply one instrument that can be used in the study of a research problem. The 
BORJU: Borneo Educational Journal https://jurnal.fkip-uwgm.ac.id/index.php/Borju/index

E-ISSN:

Februari 2019, Vol. 1 No. 1

questionnaire consists of 22 items. The questionnaires were used five alternatives based on the Likert's Scale Types (Wade, 2006). Likert's scale is used to measure attitude, opinion, perception based on certain object or phenomenon.

Table 3.1 Indicators of Likert's scale

\begin{tabular}{llcc}
\hline No & Indicators & \multicolumn{2}{c}{ Score } \\
\hline & & Positive Question & Negative Question \\
\hline A. & Always & 5 & 1 \\
B. & Often & 4 & 2 \\
C. & Sometimes & 3 & 3 \\
D. & Seldom & 2 & 4 \\
E. & Never & 1 & 5 \\
& & & \\
\hline
\end{tabular}

On the other hands, the questionnaire was given to the students consist of many indicators. Indicators were taken from Cesar (2011) theory about the reading habit aspects, they are: reading number of books, academic reading, reading frequency, non- academic reading, reading motivation.

Table 3.2 Indicators of Reading Habit

\begin{tabular}{lll}
\hline No & Reading Habit Indicators & Item Numbers \\
\hline 1 & Reading Number of Books & $1,2,3,4$, \\
2 & Academic Reading & $5,6,7,8,9$ \\
3 & Reading Frequency & $10,11,12,13$, \\
4 & Non-Academic Reading & $14,15,16$ \\
5 & Motivation in the Academic Environment & $17,18,19,20,21$ \\
6 & Motivation in the Family Environment & 22
\end{tabular}

In addition, reading the test was administering to measure the students' reading comprehension ability in English. This test was adopted from TOEFL test in reading comprehension section. Thus, the students were instructed to finish the test and complete the questionnaire in 60 minutes.

The data from questionnaire and reading test were analyzed by using Pearson Product moment Correlation in order to investigate whether there was significant correlation between students' reading habit in English and students' reading comprehension ability or not. The data was statistically computed through the Statistical Package for Social Science (SPSS) version 22. 


\section{FINDINGS AND DISCUSSION}

\section{The Result of Questionnaire}

From the data questionnaire, it was found that there was 1 student whose high reading habit $(3 \%), 4$ students had medium score $(11 \%)$, the majority of them had low reading habits 28 students $(74 \%)$ and 5 students had very low reading habit $(13 \%)$. Based on the result of analysis on student answer of the questionnaire, it can be seen that students still have low reading habit.

This finding is similar to previous research done by Wulandari (2016) emphasized that good reading habit results better academic performance. However, regarding to the finding of this study, the students' reading habit is quite low that may influence their reading comprehension. In Indonesia, this issue is quite common because most of Indonesian is not accustomed with reading. Their reading interest is also low, therefore they do not read too much, meaning that, causing the low reading habit. Moreover, it was in line with theory of Laksmi (2007) which say that to understand the meaning of reading or reading habit, the only way is to read. Meanwhile, Cesar's (2011) said that the reading habit factors related to academic performance are the attitude the student has towards reading.

\section{The Result of Reading Test}

Relating to students' reading comprehension ability, most of students are in the level of low reading comprehension ability, about $95 \%$ students. This result is in line with the result of reading habit. In line with theory of Mahfoodh (2016) mentioned that the students had also some difficulties that were related to English, which was not their first language. Insufficient educational background and did not interest in reading English were also one of the difficulties that affected students' reading comprehension. As Astomo (2016) said that if the students have a good interest in reading on English text, they will be able to get the high score in reading comprehension. Whereas, if they did not have a good interest, they are not enthusiastic to read English text, so it indicates that they have low ability on reading comprehension. On the other hands, Iskandar (2016) study also supports the current study finding by saying that in learning reading comprehension are students have no good vocabulary mastery, the student do not understand what they read, they have no the ability to decode and master sight words then they cannot comprehend the text.

\section{Reading Habit in Relation to Reading Comprehension}

From the finding above, it is clearly seen that there is significant correlation between reading habit and reading comprehension ability, in which, reading habit influences reading comprehension ability about $43 \%$. The other $57 \%$ are other factors that influence student's reading comprehension. In a similar study by Hidayah (2013) it was concluded that there is a significant correlation between reading habit in English and reading comprehension. This finding is also supported by Costa's (2013) finding stating that the both variables are correlated. As Wulandari (2016) found that reading habit and reading comprehension ability have related each other. Since their reading habit is considered low, it causes their reading comprehension ability decreased. Habits for reading are viewed as significant effect on the successfulness of students' reading comprehension, while comprehension itself is the result of a good reading habit process. 
In addition, reading habit assist the students to be more familiar with the vocabulary and also help students be more confident in speaking English. Muawanah (2014) states that with reading habit, students easily understanding the material without any complications. Familiarize the reading habit will be very helpful in developing student's comprehension skill. Every comprehension task they already got then they automatically predict the error in the passage, and they more accurately. Baironi et al. (2010) also added that reading habit is a routine activity that can increase students' reading comprehension. However, if students good in reading habit then they also good in reading comprehension and if student's poor in reading habit then they also poor in their reading comprehension.

\section{CONCLUSION}

Based on the description of the data analysis and data findings, it can be concluded that students' reading comprehension is influenced by students' reading habit. In addition, to increase students reading comprehension, it is needed to improve students reading habit. Furthermore, students who have good result in their reading comprehension test because the result of the test showed that students in good habit material have positive result on their reading comprehension. From the result of this research, it can be seen from the result of the hypothesis testing which shows that the correlation is significant, the magnitude of the significant value is 0.000 lower than 0.05 . Thus, it can be synthesized that the alternative hypothesis ( $\mathrm{Ha}$ ) is accepted and the null hypothesis is rejected. It means that there is the correlation between students' reading habit in English and students' reading comprehension at second semester of English Department in Widya Gama Mahakam Samarinda in academic year 2018/2019. Therefore, it can be seen that the reading habit considerably influence reading comprehension which shows that if the students' got low score in reading habit they tended to get low score in reading comprehension. 


\section{BIBLIOGRAPHY}

[1] A. Hamra and E. Syatriana, "A model of reading teaching for university EFL students: Need analysis and model design," English Lang. Teach., vol. 5, no. 10, pp. 1-11, 2012.

[2] S. Gilroy, "Rowan Digital Works Relationships between reading habits and the development of study skills," 2008.

[3] I. M. Alfaki and A. G. Siddiek, "The Role of Background Knowledge in Enhancing Reading Comprehension," vol. 3, no. 4, 2013.

[4] A. Abdullah and O. Mahfoodh, Academic reading difficulties encountered by international graduate students in a Malaysian university, vol. 6. 2016.

[5] M. T. Siniscalco and N. Auriat, "Questionnaire design: Module 8; Quantitative research methods in educational planning; 2005," 2015.

[6] B. Gardner, P. Lally, and J. Wardle, "Making health habitual: the psychology of 'habitformation' and general practice,” Br. J. Gen. Pract., vol. 62, no. 605, pp. 664-666, Dec. 2012.

[7] U. Thomas-fair, "The Power of Prediction: Using Prediction Journals to increase comprehension in kindergarten."

[8] P. Nilsen, K. Roback, A. Broström, and P.-E. Ellström, "Creatures of habit: accounting for the role of habit in implementation research on clinical behaviour change," Implement. Sci., vol. 7, no. 1, p. 53, 2012.

[9] J. T. Guthrie and S. L. Klauda, "Effects of Classroom Practices on Reading Comprehension, Engagement, and Motivations for Adolescents," Read. Res. Q., vol. 49, no. 4, pp. 387-416, Oct. 2014.

[10] D. Smith, "Engineer envisions sci-fi as reality," Arkansas Online, vol. 5, pp. 413-418, 2014.

[11] C. Perfetti and J. Stafura, "Word knowledge in a theory of reading comprehension," Sci. Stud. Read., vol. 18, no. 1, pp. 22-37, 2014.

[12] E. Ernawati, "Tell Tale Increasing Skill : Increasing Indonesian Student Reading Comprehension," no. 2014, pp. 577-587.

[13] W. Vagias, "Likert-type scale response anchors," Clemson Int. Inst. Tour. Res. Dev. Dep. Park. Recreat. Tour. Manag., pp. 3-4, 2006.

[14] E. Iftanti, "What Makes Efl Students Establish Good Reading Habits in English," Int. J. Educ. Res., vol. 3, no. 5, pp. 365-374, 2015.

[15] M. F. Patel and P. M. Jain, English Language: Methods, Tools \& Techniques. 2008.

[16] N. Hidayah, "the Correlation Between Reading Habit in English and Reading Comprehension At Second," 2014.

[17] P. Dinis, P. A. Almeida, and L. Araújo, Reading Literacy in EU Countries : Evidences from PIRLS. . 
[18] M. L. Roit Edd, "Effective Teaching Strategies for Improving Reading Comprehension in k-3 Students," SRA Open Court Read., 2016.

[19] J. Cesar, G. Gaona, E. Rogelio, and V. González, “of psychology students,” vol. XL, no. 157, pp. 55-73, 2011.

[20] D. R. N. Arbain Akhmad Taufik, Truong Thi Nhu Ngoc, "Basic English Drill." https://books.google.co.id/books?id=aLNF, 2017.

[21] J. W. Creswell, Educational research: Planning, conducting, and evaluating quantitative and qualitative research, vol. 4. 2012.

[22] Educational Research. Pearson, 2012.

[23] N. Yuliyanti, S. Hikmah, and M. Masrupi, “THE INFLUENCE OF RECIPROCAL TEACHING STRATEGY AND READING HABIT TOWARD STUDENTS'ACHIEVEMENT ON READING COMPREHENSION AT THE EIGHT GRADE OF MTS AL HASYIMIYAH," Proceeding AISELT, pp. 365-378, 2018.

[24] D. R. N. Arbain Akhmad Taufik, “Daily English Phrases Book.” 2017. 